\title{
International Welfare Effects of Monetary Policy
}

\section{Tervala, Juha}

Aboa Centre for Economics

2011

Tervala , J 2011, International Welfare Effects of Monetary Policy . Aboa Centre for Economics Discussion Papers, no. 66 , Aboa Centre for Economics, Turku .

http://hdl.handle.net/10138/39191

submittedVersion

Downloaded from Helda, University of Helsinki institutional repository.

This is an electronic reprint of the original article.

This reprint may differ from the original in pagination and typographic detail.

Please cite the original version. 
Juha Tervala

International Welfare Effects of Monetary Policy

\section{Aboa Centre for Economics}

Discussion Paper No. 66

Turku 2011

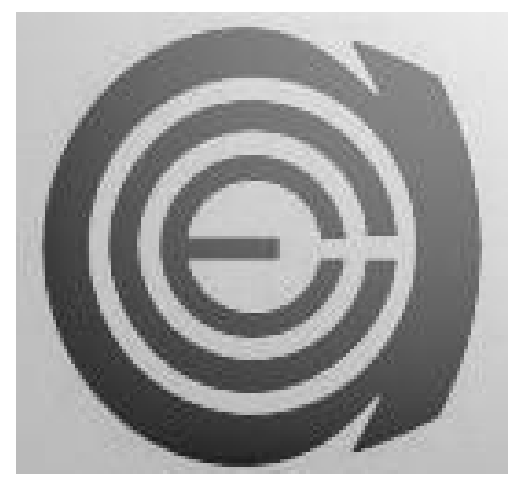


Copyright $(\odot$ Author(s)

ISSN 1796-3133

Printed in Uniprint

Turku 2011 


\title{
Juha Tervala \\ International Welfare Effects \\ of Monetary Policy
}

\author{
Aboa Centre for Economics \\ Discussion Paper No. 66 \\ April 2011
}

\begin{abstract}
In this paper, I examine the international welfare effects of monetary policy. I develop a New Keynesian two-country model, where central banks in both countries follow the Taylor rule. I show that a decrease in the domestic interest rate, under producer currency pricing, is a beggar-thyself policy that reduces domestic welfare and increases foreign welfare in the short term, regardless of whether the cross-country substitutability is high or low. In the medium term, it is a beggar-thy-neighbour (beggar-thyself) policy, if the Marshall-Lerner condition is satisfied (violated). Under local currency pricing, a decrease in the domestic interest rate is a beggar-thy-neighbour policy in the short term, but a beggarthyself policy in the medium term. Both under producer and local currency pricing, a monetary expansion increases world welfare in the short term, but reduces it in the medium term.

JEL Classification: E32, E52, F30, F41, F44

Keywords: Open economy macroeconomics, monetary policy, beggar-thyself, beggar-thy-neighbour, Taylor rule, welfare analysis
\end{abstract}




\section{Contact information}

Juha Tervala

Aboa Centre for Economics and University of Turku

Email: juha.tervala@utu.fi 


\section{Introduction}

Monetary policies of the U.S. Federal Reserve (Fed) and the European Central Bank have notable consequences, not only on their own economies but also on the rest of the world. The Fed implemented a monetary expansion after the 2001 recession, which lowered the short-term nominal interest rate in 2003, at a time when output may have been quite close to its natural level, by more than the Taylor rule suggested. After this, the Fed gradually raised the interest rate to a level coinciding with the appropriate level of interest rate, as implied by the Taylor rule (see Taylor 2009). Understanding the international welfare effects of this type of monetary policy is essential. This paper analyses the international welfare effects of monetary policy in a situation where the central bank unexpectedly lowers the interest rate and then gradually raises it back to the level implied by the Taylor rule.

Analysing the international welfare effects of monetary policy has received attention in the so-called New Open Economy Macroeconomics (NOEM) literature, pioneered by Obstfeld and Rogoff $(1995,1996)$. This is hardly a surprise, since one advantage of the NOEM framework is that it allows an explicit utility-based welfare analysis of monetary policy. Obstfeld and Rogoff (1995) demonstrate that the benefits of a domestic monetary expansion are split equally between the home and foreign country. They focus on the case where the elasticity of substitution between domestic and foreign goods (cross-country substitutability, for short) is high, and export prices are set in the producer's currency (PCP, producer currency pricing).

The subsequent NOEM literature has shown that the international welfare effects of monetary shocks are predicated by the currency of export pricing and the cross-country substitutability. Betts and Devereux (2000) show that if export prices are set in the local currency of the consumer (LCP, local currency pricing), a monetary expansion is a beggar-thy-neighbour policy. The reason is that the domestic country can improve its terms of trade at the neighbour's expense. Corsetti and Pesenti (2001) and Tille (2001) show that expansionary monetary policy is beggar-thyself if the cross-country substitutability is lower than the elasticity of substitution between two goods produced in the same country (within-country substitutability, for short). Also in this case, gains in domestic output are offset by deteriorating terms of trade.

The studies of Betts and Devereux (2000), Corsetti and Pesenti (2001), Obstfeld and Rogoff (1995) and Tille (2001) analyse only the overall welfare effect. That is, they focus exclusively on the discounted present value of the change in utility. Engler and Tervala (2010) instead analyse the behaviour of welfare over time. They show that the models of Corsetti and Pesenti 
(2001), Obstfeld and Rogoff (1995) and Tille (2001) in the end generate a common result: A monetary expansion is a beggar-thyself policy in the short term, regardless of whether the cross-country substitutability is equal to or smaller than the within-country substitutability. On the other hand, in the long term, it is a beggar-thyself policy only if the Marshall-Lerner condition does not hold.

Vanhoose (2004) criticised the NOEM literature because it abstracted from much that the field of monetary economics has learned about monetary policy modelling. On one hand, the revival of interest-rate rules, pioneered by Taylor (1993) and Woodford (2003), have become an essential part of the NOEM literature after Vanhoose wrote the critical appraisal. On the other hand, in all above-mentioned studies that address the international welfare effects of monetary policy, a monetary expansion is a simple shock to the money supply and the foreign country does not respond to it.

The main point of this paper is to analyse the international welfare effects of monetary policy in a case where the central banks in both countries follow the Taylor rule with interest rate smoothing. Monetary expansion means a negative shock to the domestic Taylor rule. Therefore, the domestic central bank unexpectedly lowers the interest rate and gradually raises it to the level implied by the Taylor rule. The central bank in the foreign country follows the Taylor rule the whole time.

One of the main findings of the paper is that the overall welfare effects of a decrease in the interest rate are completely the same in all models - Engler and Tervala (2010), Obstfeld and Rogoff (1995), Corsetti and Pesenti (2001) and Tille (2001) - in which the money supply is permanently increased. Therefore, a decrease in the interest rate can: (i) be a beggar-thy-neighbour policy (in the case of LCP); (ii) be a beggar-thyself policy (in the case of PCP with a low cross-country substitutability); or (iii) increase utility in both countries (in the case of PCP with a high cross-country substitutability).

The international welfare effects of monetary policy over time, however, depend differently on the currency of export pricing and the cross-country substitutability than overall welfare effects. In the short term, under PCP, a monetary expansion always has a beggar-thyself effect, regardless of the size of the cross-country substitutability. In the medium term, however, a monetary expansion has a beggar-thy-neighbour effect if the Marshall-Lerner condition holds, but a beggar-thyself effect if the Marshall-Lerner condition does not hold. ${ }^{1}$ In addition, a monetary expansion has, in the medium term,

\footnotetext{
${ }^{1}$ The Marshall-Lerner condition is that the sum of the elasticities of demand for exports and imports exceed one in absolute value. Under certain assumptions, this is the condition for a depreciation to improve the trade balance (Deardorff 2011).
} 
a beggar-thyself effect under LCP, although short-term and overall effects are beggar-thy-neighbour. On the other hand, the welfare effects of monetary policy on world welfare is not sensitive to the currency of export pricing and the cross-country substitutability: monetary expansion always increases world utility in the short term and reduces it in the medium term.

Bluedorn and Bowdler (2011) analyse empirically the effects of a contractionary U.S. monetary policy shock on U.S and non-U.S. G7 countries. Their main findings are as follows. First, it induces an impact appreciation of the dollar that is followed by a gradual return roughly to the initial level. Second, there is positive interest rate pass-through from the U.S. to the non-U.S. G7 countries. U.S. monetary policy, however, creates deviations from uncovered interest rate parity (UIP). Third, U.S. output response is negative, while non-U.S. G7 countries' output shows a mixed initial response (some positive and some negative). In the short term, the PCP version of the present model is able to capture all of these open economy consequences of U.S. monetary policy. Non-U.S. G7 countries might have different cross-country elasticities with the United States, which might explain some positive and some negative foreign output responses.

The rest of the paper is organised as follows. Section 2 presents the model where all PCP is used. Section 3 discusses the international transmission effects of monetary policy in the PCP case. Section 4 presents the LCP version of the model and analyses the international transmission effects of monetary policy in the LCP case. Section 5 concludes the paper.

\section{Model}

In this section, I develop a New-Keynesian open-economy model characterized by imperfect competition and nominal rigidities. The main modelling innovation relative to the previous studies that have analysed the welfare effects of monetary policy in open economies - Betts and Devereux (2000), Corsetti and Pesenti (2001), Engler and Tervala (2010), Obstfeld and Rogoff (1995) and Tille (2001) - is the introduction of the Taylor rule, which central banks in both countries follow. Therefore, monetary shocks are modelled as a shock to the interest rate rule, rather than a simple shock to the money supply.

The use of the Taylor rule implies that the model must be stationary. There are a number of ways to render an open economy model (with incomplete but integrated financial markets) stationary (see Schmitt-Grohe and Uribe 2003). To render the present model stationary, following Bergin (2006) and Cenesis and Pierdzioch (2010), I extended UIP by the introduction of a 
risk premium term that is a function of the level of net foreign debt. This forces wealth allocations in the long term to return to their initial levels.

The world economy consists of two countries: home and foreign. There is a continuum of firms and households that are indexed by $z \in[0,1]$. The fraction of domestic (foreign) firms and household is $n(1-n)$. Each firm produces a differentiated good, and nominal price rigidity is introduced by the mechanism proposed by Calvo (1983). In the first version of the model, I restrict the attention to the PCP case. In section 4, I extend the model by assuming LCP. In the description of the model that follows, in the cases in which the equations are symmetric across countries, I only discuss domestic equations.

\subsection{Households}

\subsubsection{Preferences}

All households have identical preferences. The intertemporal utility function of the representative domestic household can be written as

$$
U_{t}(z)=\sum_{s=t}^{\infty} \beta^{s-t}\left[\log C_{s}-\frac{\left(\ell_{s}(z)\right)^{2}}{2}\right]
$$

where $\beta$ is the discount factor, $C_{t}$ is a consumption index (defined below) and $\ell_{t}(z)$ denotes labour supply. The overall consumption index takes the following form

$$
C_{t}=\left[n^{\frac{1}{\rho}}\left(C_{t}^{h}\right)^{\frac{\rho-1}{\rho}}+(1-n)^{\frac{1}{\rho}}\left(C_{t}^{f}\right)^{\frac{\rho-1}{\rho}}\right]^{\frac{\rho}{\rho-1}},
$$

where $C_{t}^{h}\left(C^{f}\right)$ is an index of domestic (foreign) goods and $\rho>0$ measures the elasticity of substitution between domestic and foreign goods. Using the terminology of Tille (2001), I refer to $\rho$ as the cross-country substitutability. Consumption of domestic $c_{t}^{h}(z)$ and foreign $c_{t}^{f}(z)$ goods and are CES aggregates of the different brands of domestic and foreign goods

$$
C_{t}^{h}=\left[n^{-\frac{1}{\theta}} \int_{o}^{n}\left(C_{t}^{h}(z)\right)^{\frac{\theta-1}{\theta}} d z\right]^{\frac{\theta}{\theta-1}}, \quad C_{t}^{f}=\left[(1-n)^{-\frac{1}{\theta}} \int_{n}^{1}\left(C_{t}^{f}(z)\right)^{\frac{\theta-1}{\theta}} d z\right]^{\frac{\theta}{\theta-1}},
$$

where $\theta>1$ is the elasticity of substitution between goods produced in the same country. Using the terminology of Tille (2001), I refer to $\theta$ as the within-country substitutability. 
Given the consumption indexes, the optimal allocation of consumption between different types of goods is governed by the following equations:

$$
\begin{gathered}
C_{t}^{h}(z)=\left[\frac{p_{t}^{h}(z)}{P_{t}^{h}}\right]^{-\theta}\left[\frac{P_{t}^{h}}{P_{t}}\right]^{-\rho} C_{t}, \quad C_{t}^{f}(z)=\left[\frac{p_{t}^{f}(z)}{P_{t}^{f}}\right]^{-\theta}\left[\frac{P_{t}^{f}}{P_{t}}\right]^{-\rho} C_{t}, \\
C_{t}^{* h}(z)=\left[\frac{p_{t}^{* h}(z)}{P_{t}^{* h}}\right]^{-\theta}\left[\frac{P_{y}^{* h}}{P_{t}^{*}}\right]^{-\rho} C_{t}^{*}, \quad C_{t}^{* f}(z)=\left[\frac{p_{t}^{* f}(z)}{P_{t}^{* f}}\right]^{-\theta}\left[\frac{P_{t}^{* f}}{P_{t}^{*}}\right]^{-\rho} C_{t}^{*} .
\end{gathered}
$$

In these equations, asterisks indicate consumption by the representative foreign households. This means that $C_{t}^{* h}(z)\left(C_{t}^{* f}(z)\right)$ denotes consumption of the differentiated domestic (foreign) good by the representative foreign household.

The domestic currency price of domestic and foreign goods are denoted by $p_{t}^{h}(z)$ and $p_{t}^{f}(z)$ respectively. $P_{t}^{h}$ and $P_{t}^{f}$ (defined below) are respectively the price indexes corresponding to domestic and foreign consumption baskets $C_{t}^{h}(z)$ and $C_{t}^{f}(z)$, and $P_{t}$ (defined below) is the domestic consumer price index. All these price indexes are expressed in domestic currency terms. Corresponding foreign currency price indexes are denoted by an asterisk. For instance, $p_{t}^{* h}(z)$ and $p_{t}^{* f}(z)$ are respectively the foreign currency price of domestic and foreign goods.

The domestic price indexes are given by

$$
\begin{gathered}
P_{t}^{h}=\left[n^{-1} \int_{0}^{n} p_{t}^{h}(z)^{1-\theta} d z\right]^{\frac{1}{1-\theta}}, \quad P_{t}^{f}=\left[(1-n)^{-1} \int_{n}^{1} p_{t}^{f}(z)^{1-\theta} d z\right]^{\frac{1}{1-\theta}} \\
P_{t}=\left[n\left(P_{t}^{h}\right)^{1-\rho}+(1-n)\left(P_{t}^{f}\right)^{1-\rho}\right]^{\frac{1}{1-\rho}} .
\end{gathered}
$$

The corresponding foreign indexes are defined in an analogous way.

The law of one price holds for each good: $p_{t}^{h}(z)=S_{t} p_{t}^{* h}(z)$, where $S$ is the nominal exchange rate (the domestic currency price of foreign currency). This implies that the purchasing power parity (PPP) holds: $P_{t}=S_{t} P_{t}^{*}$.

\subsubsection{Budget Constraints and the Structure of Financial Markets}

Consider a cashless economy, where the only role for money is a unit of account in which bonds, wages, prices and profits are expressed. The budget constraint of the domestic representative household, in nominal terms, is given by

$$
D_{t}=\left(1+i_{t}\right) D_{t-1}+w_{t} \ell_{t}-P_{t} C_{t}+\pi_{t}
$$


$D_{t}$ denotes bonds (that pay one unit of domestic currency in period $t+1$ ) held at the beginning of period $t ; i_{t}$ is the nominal interest rate on bonds between $t-1$ and $t ; w$ is the nominal wage paid to the household in a competitive labour market; and $\pi$ denotes the household's share of the nominal profits (dividends) of domestic firms. All domestic (foreign) households own an equal share of all domestic (foreign) firms.

The structure of the foreign economy is identical to the domestic economy, with one difference. The domestic bond, denominated in the domestic currency, is the only internationally traded asset. The foreign bond $\left(F^{*}\right)$, denominated in the foreign currency, is not traded internationally. Therefore, foreign households can hold both domestic and foreign bond, while domestic households can hold only domestic bonds.

The budget constraint of a representative foreign household is

$$
\frac{D_{t}^{*}}{S_{t}}+F_{t}^{*}=\left(1+i_{t}\right) \frac{D_{t-1}^{*}}{S_{t}}+\left(1+i_{t}^{*}\right) F_{t-1}^{*}+w_{t}^{*} \ell_{t}^{*}-P_{t}^{*} C_{t}^{*}+\pi_{t}^{*} .
$$

The global asset-market-clearing condition for domestic bonds requires $n D_{t}+$ $(1-n) D_{t}^{*}=0$. In addition, since there is only one representative household in the foreign country, the net supply of the foreign bond is zero in equilibrium.

The fact that foreign households must be indifferent between holding domestic and foreign bonds leads to UIP. However, a common property of loglinearized NOEM models, with incomplete but integrated financial markets, is that shocks can lead to permanent wealth reallocations between countries. This induces nonstationarity and prevents the use of the Taylor rule.

One of the simplest ways to render the model stationary is to include a risk premium to UIP. As emphasised by Bergin (2006), for instance, the introduction of the "risk premium" term that is a function of the level of debt forces wealth allocations in the long term to return to their initial levels. This approach is used in this paper. As further emphasised by Bergin (2006), the term can be interpreted as a risk premium, because this formulation implies that lenders demand a higher rate of return on a country with a large debt to compensate for perceived default risk.

The log-linear version of UIP with a risk premium $(\psi)$ can be written as

$$
(1-\beta) \hat{\imath}_{t}=(1-\beta) \hat{\imath}_{t}^{*}+\hat{S}_{t+1}-\hat{S}_{t}-\psi \hat{D}_{t},
$$

where percentage changes from the initial steady state (denoted by the subscript zero) are denoted by hats (for example $\hat{\imath}_{t}=d i_{t} / i_{0}$ ). This formulation implies that there is a small cost that the household has to pay if its bond holdings are not equal to their steady-state level (that is zero). 


\subsubsection{Optimal Behaviour}

The optimal behaviour of households is governed by the following equations:

$$
\begin{aligned}
P_{t+1} C_{t+1} & =\beta\left(1+i_{t+1}\right) P_{t} C_{t}, \\
P_{t+1}^{*} C_{t+1} & =\beta\left(1+i_{t+1}^{*}\right) P_{t}^{*} C_{t}^{*}, \\
\ell_{t} & =\frac{w_{t}}{C_{t} P_{t}}, \\
\ell_{t}^{*} & =\frac{w_{t}^{*}}{C_{t}^{*} P_{t}^{*}} .
\end{aligned}
$$

The first-order conditions shown above are standard ones. Equations (7) and (8) are the Euler equations for optimal domestic and foreign consumption, respectively. Equations (9) and (10) show that households' optimal labour supply is an increasing function of the real wage and a decreasing function of consumption.

\subsection{Monetary Policy}

According to the Taylor rule, the central bank raises the nominal interest rate if inflation rises above the inflation target or if output rises above potential output. In this paper, in the absence of a growth path for the money supply, the inflation target is zero. As is standard in the New Keynesian literature, I define the output gap as the deviation of output from the equilibrium level that would prevail in the absence of nominal rigidities. Therefore, in the present model, the central bank responds directly to the deviation of output from the initial steady state level.

Estimates of Taylor-type monetary policy rules typically find a high degree of interest rate smoothing. Therefore, I assume that the domestic central bank follows the log-linear Taylor rule with interest rate smoothing (the foreign central bank follows an identical rule):

$$
\hat{\imath}_{t}=\left(1-\mu_{1}\right)\left(\mu_{2} \Delta P_{t}+\mu_{3} \hat{y}_{t}\right)+\mu_{1} \hat{\imath}_{t-1}+\epsilon_{i, t} .
$$

In this equation, the coefficients $\mu_{1}, \mu_{2}$ and $\mu_{3}$ are non-negative and chosen by the central banks. In addition, $\Delta$ denotes the first difference operator and $\epsilon_{i, t}$ is an unpredictable shift in the monetary policy rule. 


\subsection{Firms}

\subsubsection{Profits}

All firms produce a differentiated good and the production function of the representative domestic firm is

$$
y_{t}(z)=\ell_{t}(z)
$$

where $y(z)$ is the total output of firm $z$ and $\ell(z)$ is the labour input used by it.

The representative domestic firm maximizes profits

$$
\pi_{t}(z)=p_{t}(z) y_{t}(z)-w_{t} \ell_{t}(z),
$$

taking into account the production function (13) and the demand curve for it products

$$
y_{t}^{d}(z)=\left[\frac{p_{t}^{h}(z)}{P_{t}^{h}}\right]^{-\theta}\left[\frac{P_{t}^{h}}{P_{t}}\right]^{-\rho} C_{t}^{W},
$$

where $C_{t}^{W}$ is the world demand $\left(C_{t}^{W}=n C_{t}+(1-n) C_{t}^{*}\right)$. The firm's profits can therefore be written as

$$
\pi_{t}(z)=\left[\frac{p_{t}^{h}(z)}{P_{t}^{h}}\right]^{-\theta}\left[\frac{P_{t}^{h}}{P_{t}}\right]^{-\rho} C_{t}^{W}\left(p_{t}^{h}(z)-w_{t}\right) .
$$

\subsubsection{International Price Setting}

In the absence of price rigidities, the representative domestic firm would maximize its profits, specified in equation (14), using $p_{t}^{h}(z)$ as the choice variable. This would imply that the optimal price is given by a simple markup, determined by the within-country substitutability, over the marginal cost, according to the formula

$$
p_{t}^{h}(z)=\frac{\theta}{\theta-1} w_{t}
$$

To model price rigidities, I follow the formulation of Calvo (1983). This implies that each firm may reset its price in any given period with a probability $1-\gamma$, independently of other firms and the amount of time since the last adjustment. Therefore, in setting its price, each firm has to take into account that there is a probability $0<\gamma<1$ in every subsequent period that it will not be able to revise its price setting decision. When setting a new price in period $t$, each firm maximises the present value of profits, weighting future profits by the probability that the price will still be effective in that 
period. Therefore, the representative firm seeks to maximise the discounted value of expected real profits

$$
\max _{p_{t}^{h}(z)} V_{t}(z)=E_{t} \sum_{s=t}^{\infty} \gamma^{s-t} Q_{t, s} \frac{\pi_{s}(z)}{P_{s}},
$$

where $E$ denotes the expectation operator and $Q_{t, s}$ is a stochastic discount factor between period $t$ and period $s$. The firm's optimization problem results in the following pricing rule:

$$
p_{t}^{h}(z)=\left(\frac{\theta}{\theta-1}\right) \frac{E_{t} \sum_{s=t}^{\infty} \gamma^{s-t} Q_{t, s}\left(\frac{C_{s}^{W}}{P_{s}}\right)\left(\frac{1}{P_{s}^{h}}\right)^{-\theta}\left(\frac{P_{s}^{h}}{P_{s}}\right)^{-\rho} w_{s}}{E_{t} \sum_{s=t}^{\infty} \gamma^{s-t} Q_{t, s}\left(\frac{C_{s}^{W}}{P_{s}}\right)\left(\frac{1}{P_{s}^{h}}\right)^{-\theta}\left(\frac{P_{s}^{h}}{P_{s}}\right)} .
$$

The log-linear version of equation (16) can be written as

$$
\hat{p}_{t}^{h}(z)=\beta \gamma E_{t} \hat{p}_{t+1}^{h}(z)+(1-\beta \gamma) \hat{w}_{t},
$$

so that the optimal price is the weighted average of the current and future nominal marginal costs.

\subsection{Symmetric Equilibrium}

All firms in a country are symmetric, and every firm that decides to change its price in any given period chooses the same price and output. The structure of price setting implies that each period a fraction of firms $(1-\gamma)$ set a new price and the remaining fraction keep their price unchanged.

The consolidated budget constraint of the home economy is derived by using equations (4) and (13): ${ }^{2}$

$$
P_{t} C_{t}=p_{t}^{h}(z) y_{t}(z)+\left(1+i_{t}\right) D_{t-1}-D_{t} .
$$

The model is log-linearized around a symmetric steady state, where all exogenous variables are constants and where initial net foreign assets are zero. Equations (9), (12) and (15) imply that the initial level of employment and output is given by

$$
y_{0}=\ell_{0}=\left(\frac{\theta-1}{\theta}\right)^{\frac{1}{2}} .
$$

Equilibrium is defined as sequences of variables that clear the labour, goods and money markets in each country in each period and satisfy intertemporal budget constraints and pricing rules.

\footnotetext{
${ }^{2}$ The corresponding foreign equation, taking into account the global asset-marketclearing condition for domestic bonds $\left(n D_{t}+(1-n) D_{t}^{*}=0\right)$ and that the net supply of the foreign bond is zero in equilibrium, is $P_{t}^{*} C_{t}^{*}=p_{t}^{* f}(z) y_{t}^{*}(z)-\left(1+i_{t-1}\right) \frac{n}{1-n} \frac{D_{t-1}}{S_{t}}+\frac{n}{1-n} \frac{D_{t}}{S_{t}}$.
} 


\subsection{Choice of Parameter Values}

The rationale for the choice of parameter values is as follows. Periods are interpreted as quarters and, therefore, the discount factor $\beta$ is set to 0.99 . The two countries are assumed to be of equal size. Therefore, $n$ is set to 0.5 . The price rigidity parameter $\gamma$ is set to 0.5 , implying that the average time until a new price is reset is two periods (six months). This is consistent with the empirical findings of Bils and Klenow (2004). The risk premium in UIP $(\psi)$ is set to 0.0004 , based on the empirical estimates of Bergin (2006). The within-country substitutability $(\theta)$ is set to 6 .

As shown in the earlier literature - Tille (2001) and Engler and Tervala (2010) - the crucial parameter that governs the international welfare effects of monetary policy is the cross-country substitutability $\rho$. In the basic setting, I have set it to 6 so that it is equal to the within-country substitutability, as in the Obstfeld- Rogoff (1995) model. This a natural benchmark to analyse the implication of varying the cross-country substitutability. The most realistic case is likely the one in which the cross-country substitutability is smaller than the within-country substitutability. Therefore, I focus on the cases where the cross-country substitutability parameter is smaller than the within country one. Specifically, I focus on the cases where $\rho=1$ and $\rho=0.5$.

Finally, the coefficients in the Taylor rule have to be defined. The interest rate smoothing parameter $\left(\mu_{1}\right)$ is set to 0.8 . This is consistent with the empirical findings of Clarida et al. (2000). Based on the original estimates of Taylor (1993), $\mu_{2}$ is set to 1.5 and $\mu_{3}$ is set to $0.5 / 4 .^{3}$

\section{Welfare Effects of Monetary Policy under Producer Currency Pricing}

\subsection{Method of Welfare Analysis}

The method of welfare analysis in this model is somewhat different than in first generation NOEM models, including Betts and Devereux (2000), Corsetti and Pesenti (2001), Obstfeld and Rogoff (1996) and Tille (2001), where all prices are fixed for one period and the economy reaches the new steady state after that period. In these models, the welfare effect is the short-term change in utility plus the discounted present value of the change in steady-state utility. Because of staggered price setting, I evaluate welfare changes as follows. First, I study changes in one period's utility. Then, I

\footnotetext{
${ }^{3}$ I solve the model using the algorithm developed by Klein (2000) and McCallum (2001).
} 
calculate the discounted present value (DPV) of the change in utility. ${ }^{4}$

Formally, the change in utility in period $t$ is given by

$$
d U_{t}=\hat{C}_{t}-\bar{\ell}_{0}^{2} \hat{\ell}_{t}
$$

while an analogous expression holds for foreign utility. The DPV of the change in utility is therefore calculated as

$$
d U_{D P V}=\sum_{s=t}^{\infty} \beta^{s-t} d U_{s},
$$

with an equivalent expression holding for the foreign country. The change in world utility is defined as the population weighted sum of the change in domestic and foreign utility, as follows:

$$
d U_{i}^{W}=n d U_{i}+(1-n) d U_{i}^{*}
$$

where $i=t, D P V$.

Table 1: Welfare Effects of a Domestic Interest Rate Shock under PCP

\begin{tabular}{|c|c|c|c|c|c|c|c|c|}
\hline & $d U_{1}$ & $d U_{1}^{*}$ & $d U_{1}^{W}$ & $d U_{6}$ & $d U_{6}$ & $d U_{6}^{W}$ & $d U_{s s}$ & $d U_{s s}^{*}$ \\
\hline$\rho=0.5$ & -0.0041 & 0.0078 & 0.0019 & -0.0005 & 0.0003 & -0.0001 & 0 & 0 \\
\hline$\rho=1$ & -0.0075 & 0.011 & 0.0019 & 0.0002 & -0.0003 & -0.0001 & 0 & 0 \\
\hline$\rho=3$ & -0.016 & 0.02 & 0.0019 & 0.0013 & -0.0014 & -0.0001 & 0 & 0 \\
\hline$\rho=6$ & -0.023 & 0.027 & 0.0019 & 0.0018 & -0.019 & -0.0001 & 0 & 0 \\
\hline
\end{tabular}

Figures 1-4 illustrate the changes in the period's utility. Table 1 shows these changes in the period's utility in the first and sixth period and in the steady state (SS). Table 2 shows the DPV of the change in utility.

Table 2: Discounted Present Value of the Change in Utility under PCP

\begin{tabular}{|c|c|c|c|}
\hline & $d U_{D P V}$ & $d U_{D P V}^{*}$ & $d U_{D P V}^{W}$ \\
\hline$\rho=0.5$ & -0.02 & 0.024 & 0.0023 \\
\hline$\rho=1$ & -0.091 & 0.014 & 0.0023 \\
\hline$\rho=3$ & -0.0049 & 0.005 & 0.0023 \\
\hline$\rho=6$ & 0.0023 & 0.0023 & 0.0023 \\
\hline
\end{tabular}

\footnotetext{
${ }^{4}$ The same method is used in Ganelli and Tervala (2010) and Tervala (2010).
} 


\subsection{Welfare Effects in the Basic Case}

I begin by examining the dynamic effects of $-1 \%$ shock $\left(\epsilon_{i, 1}=-1\right)$ to the domestic monetary policy rule in the basic case, where the cross-country substitutability is equal to the within-country substitutability $(\rho=\theta=6)$. I will discuss how responsive the welfare effects of monetary are to changes the cross-country substitutability later in this paper.

Figure 1 (on page 26) shows the effects of a decrease in the domestic interest rate. In all figures, the vertical axes show percentage deviations from the initial steady state, except for the change in bond holdings, which are expressed as a deviation from initial consumption. The domestic terms of trade are defined as the relative price of domestic exports in terms of imports. The domestic terms of trade, therefore, worsen if this index falls. It is worth mentioning that the economy has not yet reached the new steady state after ten periods.

Panel (c) in Figure 1 shows that a decrease in the domestic interest rate depreciates the nominal exchange rate. In the short and medium term, the domestic interest rate is low relative to the foreign interest rate. UIP then implies that this is only consistent with expected exchange rate appreciation. Therefore, the exchange rate must overshoot its long-term level; it must initially depreciate to a point where it will appreciate until it reaches the steady-state level.

The depreciation of the nominal exchange rate raises the relative price of foreign goods, shifting world demand toward domestic goods and away from foreign goods. This traditional expenditure-switching effect of a nominal exchange rate change causes an increase in domestic output and a decrease in foreign output, as long as prices are sticky, as shown in panel (a) of Figure 1 .

The domestic monetary policy lowers the real interest rate and world consumption increases in the short term. The consumption differential between countries, unlike in the Obstfeld-Rogoff model, is not constant; it instead diminishes over time. The log-linear version of equation (8) can be subtracted from equation (7), making use of PPP and UIP with a risk premium, yielding

$$
\hat{C}_{t}+\psi \hat{D}_{t}-\hat{C}_{t}^{*}=\hat{C}_{t+1}-\hat{C}_{t+1}^{*} .
$$

The risk premium in UIP implies that real interest rates are not equal across countries. Consumption growth, therefore, is not equated across countries. However, since the risk premium is quite small, the households in both countries face almost the same real interest rate. This implies that the shock changes their consumption profiles almost proportionately in the short and 
medium term. The expenditure-switching effect induces an increase in relative domestic consumption. In addition, the income of domestic households is temporarily high and the domestic households have an incentive to save part of this extra income by running a current account surplus in the short term (see panel (e) in Figure 1).

Panel (a) shows that, with higher medium-term wealth, domestic households choose to decrease their labour supply, consequently decreasing domestic output in the medium term. A fall in the supply of domestic goods causes a small improvement in the domestic terms of trade in the medium term. The risk premium in UIP that is a function of the level of debt forces bond holdings in the long term to return to their initial levels. Therefore, in the medium term, domestic households use accumulated wealth to finance consumption and their bond holdings decrease gradually over time. In the long term, the bond holding of domestic households have returned to zero. Therefore, the wealth effect of bond holdings dies out and the economy reverts to the initial steady state in the long term. This is in contrast with the Obstfeld-Rogoff model, where a money supply shock has permanent real effects, because of permanent changes in international wealth allocations.

Panel (h) in Figure 1 illustrates that the foreign central bank decreases the interest rate in the short term. This is a response to deflation and the fall in output. In the medium term, the foreign central bank increases the interest rate due to inflation and the increase in output.

Table 1 and Panel (f) in Figure 1 show that domestic monetary expansion decreases domestic utility in the short term, but increases it in the medium term. The reason for the fall in short-term welfare is that the accumulation of external assets and the deterioration in the domestic terms of trade (caused by the exchange rate depreciation) together imply that domestic consumption increases less than proportionally to output (employment). In the medium term, domestic utility increases. Deaccumulation of domestic wealth allows consumption to be higher than output (recall equation (17)). This current account effect and the improvement in the terms of trade have a favourable effect on consumption and, consequently, on welfare in the medium term. In the long term, the shock is neutral and, therefore does not have welfare effects.

In the beginning, the sign of foreign welfare effects is a mirror image of domestic ones: The domestic shock increases foreign welfare in the short term, but reduces it in the medium term. The short-term welfare gain is caused by an increase in consumption and a fall in employment (output). Foreign consumption increases despite a fall in output due to an improvement in its terms of trade and the accumulation of net external debt. In the medium term, foreign households, with lower wealth, work more and output increases. 
This causes an increase in the supply of foreign goods and, therefore a deterioration of the foreign terms of trade. This terms of trade effect increases foreign consumption and welfare. In addition, foreign households must run a trade balance surplus to be able to pay back the debt. This current account channel reinforces the terms of trade channel, and consequently consumption falls, despite an increase in output. Therefore, foreign welfare decreases in the medium term.

Table 1 demonstrates that domestic monetary policy increases world utility in the short term, but decreases it in the medium term. The liquidity effect of monetary policy increases world output closer to its efficient level. Since the initial output level is inefficiently low, this automatically increases world welfare in the short term. In the medium term, inflation has decreased the real wage below the initial steady-state level and the labour supply, and consequently output falls relative to the initial steady state. This reduces world welfare in the medium term.

Most of the main results of this exercise are in line with the ObstfeldRogoff model that analyses the effects of a permanent shock to the money supply, if their long-term results are compared with the medium-term results of this paper. ${ }^{5}$ One of their main results is that the DPV of the change in utility is identical in the two countries. Table 1 shows that this is the outcome of this model as well. In the case of the domestic economy, the medium-term welfare benefits from higher consumption and lower labour supply dominate short-term welfare losses. On the other hand, in the foreign country, the medium-term welfare losses from lower consumption and higher labour supply are dominated by the short-term welfare benefits from higher consumption and lower labour supply.

In an extension to the Obstfeld-Rogoff model, Tervala (2010) analyses the evolution of welfare over time in the case of a money supply shock. That work finds that a domestic money supply shock has a beggar-thyself effect in the short term, but a beggar-thy-neighbour effect in the long term. The results of this paper are consistent with those findings, if long-term results are compared with the medium-term results of this paper, reaffirming the claim that monetary expansion is a beggar-thyself (beggar-thy-neighbour) policy in the short (medium) term.

\footnotetext{
${ }^{5}$ An exception to the Obstfeld-Rogoff (1995) model is that the nominal exchange rate does not follow the random walk. In the OR model, the relative money supplies and the consumption differential between the countries determine the nominal exchange rate. Because these are constant, the nominal exchange rate must be constant as well.
} 


\subsection{Welfare Effects when the Low Cross-Country Sub- stitutability is Low}

Corsetti and Pesenti (2001) and Tille (2001) show that the DPV of the change in utility greatly depends on the cross-country substitutability in the case of a money supply shocks. In addition, Engler and Tervala (2010) show that welfare effects over time also depend on this elasticity. In this section, I study the dependence of the welfare effects of monetary policy on the cross-country substitutability. Figure 2 (on page 27) illustrates impulse responses to the same monetary shock as in the previous section, in the cases of $\rho=1$ and $\rho=0.5$. I first focus on the case of $\rho=1$, and then analyse the case of $\rho=0.5$. Tables 1 and 2 also show welfare effects in the case of $\rho=3$, but this case is not discussed.

Panel (f) in Figure 2 shows that the behaviour of the nominal exchange rate is quite similar to the basic case $(\rho=6)$. The behaviour of the domestic interest rate, which is not shown in Figure 2, is almost the same in the previous case. The shock dominates the central bank's decisions and a different output gap, for instance, has little influence on monetary policy. In addition, the behaviour of the foreign interest rate changes only a little. For these reasons, exchange rate overshooting and gradual appreciation to the initial level are similar to the basic case.

As shown by Tille (2001), the cross-country substitutability captures the sensitivity of the consumption allocation between domestic and foreign goods with respect to the terms of trade. It therefore determines whether the consumption switching towards domestic goods following a deterioration in the domestic terms of trade is large enough to increase the sales revenues of domestic households, relative to foreign households. If $\rho>1,(\rho<1)$, domestic and foreign goods are substitutes (complements) and a deterioration in the terms of trade increases (reduces) the sales revenues. In addition, $\rho$ equals the sum of the export and import elasticities, with respect to the terms of trade. Therefore, if $\rho>1(\rho<1)$, the Marshall-Lerner condition holds (is violated) and a depreciation of the nominal exchange rate causes a current account surplus (deficit).

Panel (e) in Figure 2 illustrates that monetary policy does not cause current account imbalances in the case of $\rho=1$. This is consistent with Corsetti and Pesenti (2001) and Tille (2001). In this case, the increase in demand for domestic goods does not increase the relative sales revenues of domestic households, and consequently there is no incentive to lend and borrow internationally. The current account channel is therefore absent in this case.

The DPV of the change in utility is consistent with Corsetti and Pesenti 
(2001) and Tille (2001): Expansionary monetary policy is beggar-thyself, as gains in domestic output are offset by deteriorating terms of trade. Since the current account channel is absent in their models and money is neutral in the long term, the overall welfare effect is entirely driven by short-term welfare effects. In this and in their model(s), in the short-term, a deterioration in the terms of trade implies that a monetary shock causes an increase in domestic output without an equivalent increase in consumption. Therefore domestic utility falls. A weaker expenditure switching effect towards domestic goods, however, implies that the increase in domestic output (employment) is smaller. Domestic welfare therefore falls by less than in the basic case in the short term. This is consistent with Engler and Tervala (2010), who analyse the evolution of welfare over time in the case of a money supply shock.

Figure 2 and Table 1 reveal a noteworthy result: In the medium term, monetary policy is a beggar-thy-neighbour policy in the case of $1 \leq \rho<\theta$, despite the fall in the DPV of welfare. In the medium term, the terms of trade improve. This causes an increase in domestic consumption without an equivalent increase in output. Consequently, domestic welfare increases. The change in welfare is, however, much smaller than in the cases of $\rho=3$ or $\rho=6$. The reason is that deaccumulation of debt also increases mediumterm utility, in those cases. The increase in foreign welfare is induced by improving foreign terms of trade. Finally, Table 2 shows that the domestic shock reduces world utility in the medium term due to a fall in world output.

The next step is to discuss the international welfare effects of monetary policy in the case of $\rho=0.5$. In this case $(\rho<1)$, domestic and foreign goods are complements, which means that an increase in demand for domestic goods is followed by an increase in demand for foreign goods. Therefore, a monetary shock causes a positive cross-country correlation in output.

A monetary shock reduces domestic welfare in the short term, notwithstanding a short-term current account deficit. If the Marshall-Lerner condition does not hold, a deterioration in the terms of trade reduces the domestic sales revenue. The income of domestic households is then temporarily low and the households smooth consumption via a current account deficit in the short term. On one hand, an increase in consumption via a short-term debt accumulation tends to increase utility. On the other hand, the deterioration in the terms of trade reduces utility. The terms of effect dominates the current account effect to an extent that the increase in consumption is much smaller than the increase in output in the short term, and consequently domestic welfare reduces.

Table 1 demonstrates that the assumption of $\rho<1$, reverses the welfare effects of monetary policy in the medium term relative to the other cases: 
Monetary policy is beggar-thyself rather than beggar-thy-neighbour. In the medium term, domestic households must run a trade balance surplus to be able to pay back the external debt. This current account channel tends to reduce domestic utility. On the other hand, the terms of trade improve. The current account effect dominates the terms of trade effect to an extent that the fall in consumption is higher than the fall in output, and therefore utility reduces in the medium term.

Engler and Tervala (2010) analyse the evolution of welfare over time in the case of $\rho<1$ following a money supply shock. They find that a domestic money supply shock has a beggar-thyself effect in the short and long term. The results of this paper are consistent with those findings if their long-term results are compared with the medium-term results of this paper, reaffirming the claim that monetary expansion is always a beggar-thyself policy if the Marshall-Lerner condition does not hold.

Table 1 and 2 demonstrate that the cross-country substitutability does not affect the changes in world utility. At the world level, all that is left is the liquidity effect of monetary policy. The terms of trade and current account channels just determine allocation of pains and gains of monetary policy over time between the countries. The liquidity effect of monetary policy increases world output closer to its efficient level and increases short-term and overall utility. Temporarily, low real wage reduces world output and welfare in the medium term.

Bluedorn and Bowdler (2011) use the VAR method to empirically estimate the effects of a contractionary U.S. monetary policy shock (which raises the U.S. T-bill rate) on U.S and non-U.S. G7 countries. They find the following. First, that a monetary contraction causes an impact appreciation of the dollar that is followed by a gradual return roughly to the initial level. Second, there is positive interest rate pass-through from U.S. to non-U.S. G7 countries. U.S. monetary policy, however, creates deviations from UIP. Third, the response of U.S. output is negative, and non-U.S. G7 countries' output shows a mixed initial response (some positive and some negative).

In the short term, the PCP version of the present model is able to capture these open economy consequences of U.S. monetary policy, because the effects of contractionary monetary policy would be mirror images of those reported in this exercise. Non-U.S. G7 countries might have different cross-country elasticities with the United States, which might partly explain some positive and some negative foreign output responses. 


\section{Welfare Effects of Monetary Policy under Local Currency Pricing}

\subsection{Modifications to the Model}

Motivated by the evidence of partial exchange rate pass-through to import prices, weak empirical support for the law of one price in internationally traded goods and the sources of real exchange rate fluctuations, many researchers, including Betts and Devereux (2000, 2001), have assumed that export prices are set in the consumers' currency. Following this modelling approach, firms in each country can now "price-to-market," and these firms set their prices in the local currency of the buyer. I refer to these firms as local currency pricing (LCP) firms.

In the presence of LCP, the prices of goods are not necessarily equated across countries in the short and medium term, and PPP does not have to hold. Therefore, not only does a risk premium in UIP lead real interest rates to diverge across countries, but so does a deviation from PPP.

The equations of the model in the case of LCP are the same as earlier, unless they are explicitly discussed. However, only the equations describing the home country are shown. Under PCP, the cross-country substitutability is a key parameter for the international transmission of money shocks because it governs the strength of the expenditure switching effect. On the other hand, in the case of LCP, the depreciation of the nominal exchange rate carries no expenditure-switching effect in the short term. To keep the LCP model as simple as possible, I focus on the case where the cross-country substitutability is equal to the within-country substitutability, as in Betts and Devereux (2000). Therefore, the consumption index (2) is replaced with the following consumption index:

$$
C_{t}=\left[\int_{0}^{1} c_{t}(z)^{\frac{\theta-1}{\theta}} d z\right]^{\frac{\theta}{\theta-1}},
$$

where $c(z)$ is consumption of good $z$ and $\theta>1$ now measures the elasticity of substitution between differentiated goods. The home country CPI is now

$$
P_{t}=\left[\int_{0}^{n} p_{t}^{h}(z)^{1-\theta} d z+\int_{n}^{1} p_{t}^{f}(z)^{1-\theta} d z\right]^{\frac{1}{1-\theta}} .
$$

For domestic LCP firms, total output is divided between output sold in the home country, $x_{t}(z)$, and output sold abroad, $v_{t}(z)$. Profits of LCP firms are given by

$$
\pi_{t}^{L C P}(z)=p_{t}^{h}(z) x_{t}(z)+S_{t} p_{t}^{* h}(z) v_{t}(z)-w_{t} \ell_{t}(z),
$$


The demands for the domestic goods are given by

$$
\begin{gathered}
x_{t}(z)=\left(\frac{p_{t}^{h}(z)}{P_{t}}\right)^{-\theta} n C_{t}, \\
v_{t}(z)=\left(\frac{p_{t}^{* h}(z)}{P_{t}^{*}}\right)^{-\theta}(1-n) C_{t}^{*} .
\end{gathered}
$$

Equations (21) and (22) show the demand for a domestic LCP firm in the home and foreign country, respectively.

In the absence of nominal rigidities, domestic LCP firms would maximize $\pi_{t}^{L C P}(z)$ with respect to $p_{t}(z)$ and $p_{t}^{* h}(z)$. This would imply that

$$
p_{t}(z)=S_{t} p_{t}^{* h}(z)=\frac{\theta}{\theta-1} w_{t} .
$$

This equation shows that without nominal rigidities, the law of one price holds and good $z$ is sold at the same price in both markets, when expressed in the same currency.

With the Calvo-price setting, the representative domestic LCP firm seeks to maximize:

$$
\max _{p_{t}^{h}(z), p_{t}^{* h}(z)} V_{t}^{L C P}(z)=E_{t} \sum_{s=t}^{\infty} \gamma^{s-t} Q_{t, s} \pi_{t}^{L C P}(z),
$$

The result is that the pricing rules are given by

$$
\begin{gathered}
p_{t}^{h}(z)=\left(\frac{\theta}{\theta-1}\right) \frac{E_{t} \sum_{s=t}^{\infty} \gamma^{s-t} Q_{t, s}\left(\frac{C_{s}}{P_{s}}\right)\left(\frac{1}{P_{s}^{h}}\right)^{-\theta} w_{s}}{E_{t} \sum_{s=t}^{\infty} \gamma^{s-t} Q_{t, s}\left(\frac{C_{s}}{P_{s}}\right)\left(\frac{1}{P_{s}^{h}}\right)^{-\theta}} . \\
p_{t}^{* h}(z)=\left(\frac{\theta}{\theta-1}\right) \frac{E_{t} \sum_{s=t}^{\infty} \gamma^{s-t} Q_{t, s}\left(\frac{C_{s}^{*}}{P_{s}^{*}}\right) C_{s}^{*}\left(\frac{1}{P_{s}^{*}}\right)^{-\theta} w_{s}}{E_{t} \sum_{s=t}^{\infty} \gamma^{s-t} Q_{t, s} C_{s}^{*}\left(\frac{1}{P_{s}^{*}}\right)^{-\theta} S_{s}} .
\end{gathered}
$$

The log-linear versions of equations (23) and (24) can be written as

$$
\begin{gathered}
\hat{p}_{t}^{h}(z)=\beta \gamma E_{t} \hat{p}_{t+1}^{h}(z)+(1-\beta \gamma) \hat{w}_{t}, \\
\hat{p}_{t}^{* h}(z)=\beta \gamma E_{t} \hat{p}_{t+1}^{h}(z)+(1-\beta \gamma)\left(\hat{w}_{t}-S_{t}\right) .
\end{gathered}
$$

Equation (25) shows that domestic export prices, expressed in the foreign currency, do not change when the nominal exchange rate changes unexpectedly. This implies that exchange rate pass-through to export prices is zero for those LCP goods whose prices cannot be adjusted. 
The consolidated budget constraint of the home economy can be written as,

$$
P_{t} C_{t},=p_{t}^{h}(z) x_{t}(z)+S_{t} p_{t}^{* h}(z) v_{t}(z)+\left(1+i_{t}\right) D_{t-1}-D_{t} .
$$

In the LCP version of the model, the elasticity of substitution between differentiated goods is set to 6 . Otherwise, the choice of parameter values is the same as in the PCP version of the model.

\subsection{Results}

Figure 3 (on page 28) plots impulse response functions to domestic monetary expansion under LCP. In Figure 4 the dashed lines plot the effects of monetary policy under LCP and the solid lines under PCP in the case where $\rho=\theta=6$. Note that the only difference in these two versions of the model is the currency of export pricing.

Panel (f) in Figure 4 shows a noteworthy result: The behaviour of the nominal exchange rate under LCP is quite similar under PCP. If monetary shocks are modelled as a shock to the interest rate rule the currency of export pricing does not seem to be important for exchange rate dynamics. This is in sharp contrast to the result of Betts and Devereux (2000). They find that a shock to the money supply under LCP generates overshooting is the consumption elasticity of money demand if smaller than one, while the nominal exchange rate follows a random walk under PCP.

On one hand, the behaviour of the domestic interest rate under LCP is almost the same as in the PCP case. The shock dominates the central bank's policymaking, and a different output gap and inflation have very limited impact on interest-rate decisions. On the other hand, monetary policy in the foreign country is very different than under PCP. Due to a positive output gap and inflation, the foreign central bank raises the interest rate in the short term. In the medium term, it lowers the interest rate in response to a small negative output gap and deflation. The magnitude of the domestic interest rate movement is, however, much larger. Therefore, exchange rate overshooting and gradual appreciation to the initial level are quite similar to the PCP case.

The short-term effects of monetary policy are consistent with the findings of Betts and Devereux (2000): A monetary shock improves the terms of trade, increases domestic welfare at the neighbour expense, causes a positive (negative) cross-country correlation of output (consumption) and does not cause current account imbalances. The output effect is primarily determined by the direct demand increase by domestic households. When exchange rate pass-through to import prices is zero, the increase in demand is equally split 
between the two countries and output increases by the same amount in both countries.

An exchange rate depreciation induces only a distribution of income toward the home country, increasing domestic consumption and reducing foreign consumption. The departure from PPP implies the differential movement in real interest rates across countries and the domestic real interest rates falls. Domestic households would like to save part of high income by running a current account surplus in the short term, but the fall in the real interest rate encourages them to consume it in the present. Therefore, the low real interest rate does not encourage them to lend and LCP eliminates current imbalances. Under LCP, an exchange rate depreciation improves the terms of trade. Therefore, the positive effect of higher consumption is larger than the negative effect caused by higher employment (output). So the home country may improve its welfare, at the expense of its neighbour.

Table 3: Welfare Effects under LCP and PCP

\begin{tabular}{|l|l|l|l|l|l|l|}
\hline & $d U_{1}$ & $d U_{1}^{*}$ & $d U_{6}^{W}$ & $d U_{6}$ & $d U_{6}^{*}$ & $d U_{6}^{W}$ \\
\hline LCP & 0.016 & -0.013 & 0.0019 & -0.0004 & 0.0003 & -0.0001 \\
\hline PCP $(\rho=6)$ & -0.23 & 0.027 & 0.0019 & 0.18 & -0.019 & -0.0001 \\
\hline
\end{tabular}

Table3 and panel (f) in Figure 3 show that the short-term beggar-thyneighbour welfare effect is reversed in the medium term, when monetary policy has a beggar-thyself welfare effect. After the initial depreciation of the nominal exchange rate, it gradually appreciates. This (anticipated) appreciation causes a weak deterioration of the domestic terms of trade in the medium term, which causes a fall in real consumption and consequently in welfare. The flip side is a higher foreign consumption due to the terms of trade behaviour. This has a small positive effect on foreign welfare.

Table 4: DPV of the Change in Utility under LCP and PCP

\begin{tabular}{|c|c|c|c|}
\hline & $d U_{D P V}$ & $d U_{D P V}^{*}$ & $d U_{D P V}^{W}$ \\
\hline LCP & 0.023 & -0.019 & 0.0023 \\
\hline $\operatorname{PCP}(\theta=6)$ & 0.0023 & 0.0023 & 0.0023 \\
\hline
\end{tabular}

In the model of Betts and Devereux (2000), a money supply shock is neutral in the medium and long term. Therefore, its welfare effects are driven entirely by short-term effects. Although in the present model adjustment dynamics are more complex and monetary policy reduces domestic utility in the medium term, the models generate the same overall welfare effect (see Table 4): Monetary expansion under LCP is a beggar-thy-neighbour policy, because the domestic country can improve its terms of trade at the neighbour's expense. 
The key to the beggar-thy-neighbour result is that the domestic country can improve its terms of trade at the neighbour's expense. It is worth emphasising that the LCP model predicts that a currency depreciation is associated with an improvement in the country's terms of trade. This is inconsistent with the empirical evidence of Obstfeld and Rogoff (2000), showing that currency depreciations are associated with deteriorations rather than improvements of the terms of trade.

Finally, Table 5 shows the dependence of the sign of the welfare effect of monetary policy on the currency of export pricing and the cross-country substitutability. It shows that neither of them has impact on world utility: It is a robust result that monetary expansion increases short-term and overall world utility, but reduces medium-term utility. How the pains and gains of monetary policy are divided between countries over time, however, greatly depends on the currency of export pricing and the cross-country substitutability.

Table 5: Sign of the Welfare Effect of a Domestic Monetary Expansion

\begin{tabular}{|c|c|c|c|c|c|c|c|c|c|}
\hline & $d U_{1}$ & $d U_{1}^{*}$ & $d U_{1}^{W}$ & $d U_{6}$ & $d U_{6}$ & $d U_{6}^{W}$ & $d U_{D P V}$ & $d U_{D P V}^{*}$ & $d U_{D P V}^{W}$ \\
\hline $\mathrm{PCP}, \rho=0.5$ & - & + & + & - & + & - & - & + & + \\
\hline $\mathrm{PCP}, \rho=1$ or 3 & - & + & + & + & - & - & - & + & + \\
\hline $\mathrm{PCP}, \rho=6$ & - & + & + & + & - & - & + & + & + \\
\hline $\mathrm{LCP}$ & + & - & + & - & + & - & + & - & + \\
\hline
\end{tabular}

\section{Conclusions}

This paper focuses on the international welfare effects of monetary policy, in the context of an open-economy model with imperfect competition and nominal rigidities. The earlier literature has shown that the currency of export pricing and the cross-country substitutability have significant implications for the overall welfare effects of monetary policy, in the case where monetary policy is modelled in terms of the central bank's control of the money supply. This study shows that results do not change in any way if monetary policy in modelled in terms of an interest rate rule.

Modelling monetary policy in terms of the Taylor rule with interest rate smoothing, however, renders the evolution of welfare over time richer. For instance, under LCP, an increase in the money supply is a beggar-thy-neighbour policy in the short term without any other welfare effects (Betts and Devereux 2000). This study shows that a decrease in the interest rate, under LCP, has at first a beggar-thy-neighbour effect, and after that a beggar-thyself effect, before monetary policy becomes neutral.

The study also shows that although the effects of monetary policy on overall welfare can have the same sign in different situations, the merits and 
demerits of policy come in different time horizons. For instance, in the case where the cross-country substitutability is equal to the within-country substitutability, monetary policy increases domestic overall utility both under LCP and PCP. However, monetary policy has a beggar-thy-neighbour (beggarthyself) effect under LCP (PCP) in the short term, whereas welfare effects are reversed in the medium term. Understanding the evolution of welfare over time should be an important part of carefully implemented monetary policy although overall welfare effects are likely to be more essential. 


\section{References}

[1] Bergin, P. R. (2006): How Well Can the New Open Economy Macroeconomics Explain the Exchange Rate and Current Account? Journal of International Money and Finance 25, 675-701.

[2] Betts, C. \& Devereux, M. (2000): Exchange Rate Dynamics in a Model of Pricing-to-Market. Journal of International Economics 50, 215-244.

[3] Betts, C. \& Devereux. M. (2001): The International Effects of Monetary and Fiscal Policy in a Two-Country Model. In: Calvo, G. A., Dornbusch, R. and Obstfeld, M. (eds) Money, Capital Mobility and Trade: Essays in Honor of Robert Mundell. MIT Press, Cambridge.

[4] Bils, M. \& Klenow, P. (2004): Some Evidence on the Importance of Sticky Prices. Journal of Political Economy 112, 947-985.

[5] Bluedorn, J. C. \& Bowdler, J. (2011): The Open Economy Consequences of U.S. Monetary Policy. Journal of International Money and Finance 30, 309-336.

[6] Calvo, G. (1983): Staggered Prices in a Utility Maximizing Framework. Journal of Monetary Economics 12, 383-398.

[7] Cenesis, M. A. and Pierdzioch, P. (2010): Financial Market Integration, Costs of Adjusting Hours Worked, and Monetary Policy. Economic Notes 39, 1-25.

[8] Clarida, R., Galí, J. \& Gertler, M. (2000): Monetary Policy Rules and Macroeconomic Stability: Evidence and Some Theory. Quarterly Journal of Economics 115, 147-180.

[9] Corsetti, G. \& Pesenti, P. (2001): Welfare and Macroeconomic Interdependence. Quarterly Journal of Economics 116, 421-455.

[10] Deardorff, A. (2011): Deardorffs' Glossary of International Economics. Retrieved February 10 2011, from http://wwwpersonal.umich.edu/ alandear/glossary/intro.html.

[11] Engler, P. \& Tervala, J. (2010): Beggar-Thyself or Beggar-ThyNeighbour? The Welfare Effects of Monetary Policy. Free University of Berlin, School of Business \& Economics, Discussion Paper 2010/6. 
[12] Ganelli, G. \& Tervala, J. (2010): Public Infrastructures, Public Consumption, and Welfare in a New-Open-Economy-Macro Model. Journal of Macroeconomics 32, 827-837.

[13] Klein, P. (2000): Using the Generalized Schur Form to Solve a Multivariate Linear Rational Expectations Model. Journal of Economic Dynamics \& Control 24, 1405-1423.

[14] Lane, P. (2001): The New Open Economy Macroeconomics: A Survey. Journal of International Economics, 54, 235-266.

[15] McCallum, B. (2001): Software for RE Analysis. Computer software available at http://wpweb2.tepper.cmu.edu/faculty/mccallum/research.html

[16] Obstfeld, M. \& Rogoff, K. (1995): Exchange Rate Dynamics Redux. Journal of Political Economy 103, 624-660.

[17] Obstfeld, M. \& Rogoff, K. (1996): Foundations of International Macroeconomics. MIT Press, Cambridge.

[18] Obstfeld, M. \& Rogoff, K. (2000): New Directions for Stochastic Open Economy Models. Journal of International Economics 50, 117-153.

[19] Schmitt-Grohe, S \& Uribe, M. (2003): Closing Small Open Economy Models. Journal of International Economics 61, 163-185

[20] Taylor, J. B. (2009): Getting Off Track: How Government Actions and Interventions Caused, Prolonged, and Worsened the Financial Crisis. Hoover Institution, Stanford.

[21] Taylor, J. B. (1993): Discretion versus Policy Rules in Practice. Carnegie-Rochester Conference Series on Public Policy 39, 195-214.

[22] Tervala, J. (2010): The International Transmission of Monetary Policy in a Dollar Pricing Model. Open Economies Review 21, 629-654.

[23] Tille, C. (2001): The Role of Consumption Substitutability in the International Transmission of Monetary Shocks. Journal of International Economics 53, 421-444.

[24] Vanhoose D. D. (2004): The New Open Economy Macroeconomics: A Critical Appraisal. Open Economies Review 15, 193-215.

[25] Woodford, M. (2003): Interest and Prices: Foundations of a Theory of Monetary Policy. Princeton University Press, Princeton. 
Figure 1: Dynamic Effects of a Shock to the Domestic Monetary Policy Rule in the Basic Case $(\rho=\theta=6)$
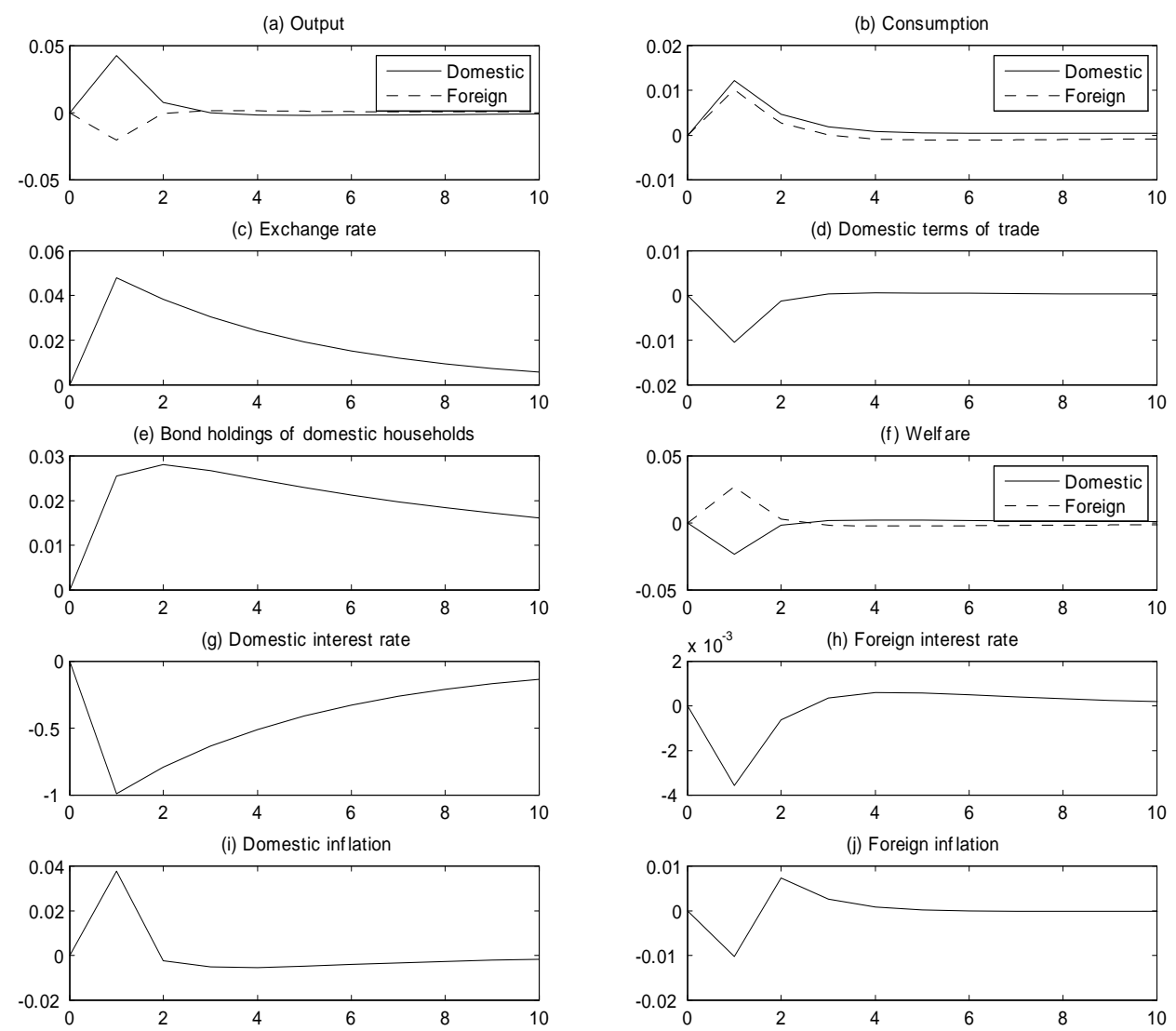
Figure 2: Dynamic Effects of a Domestic Monetary Shock: The Role of Cross-Country Elasticity
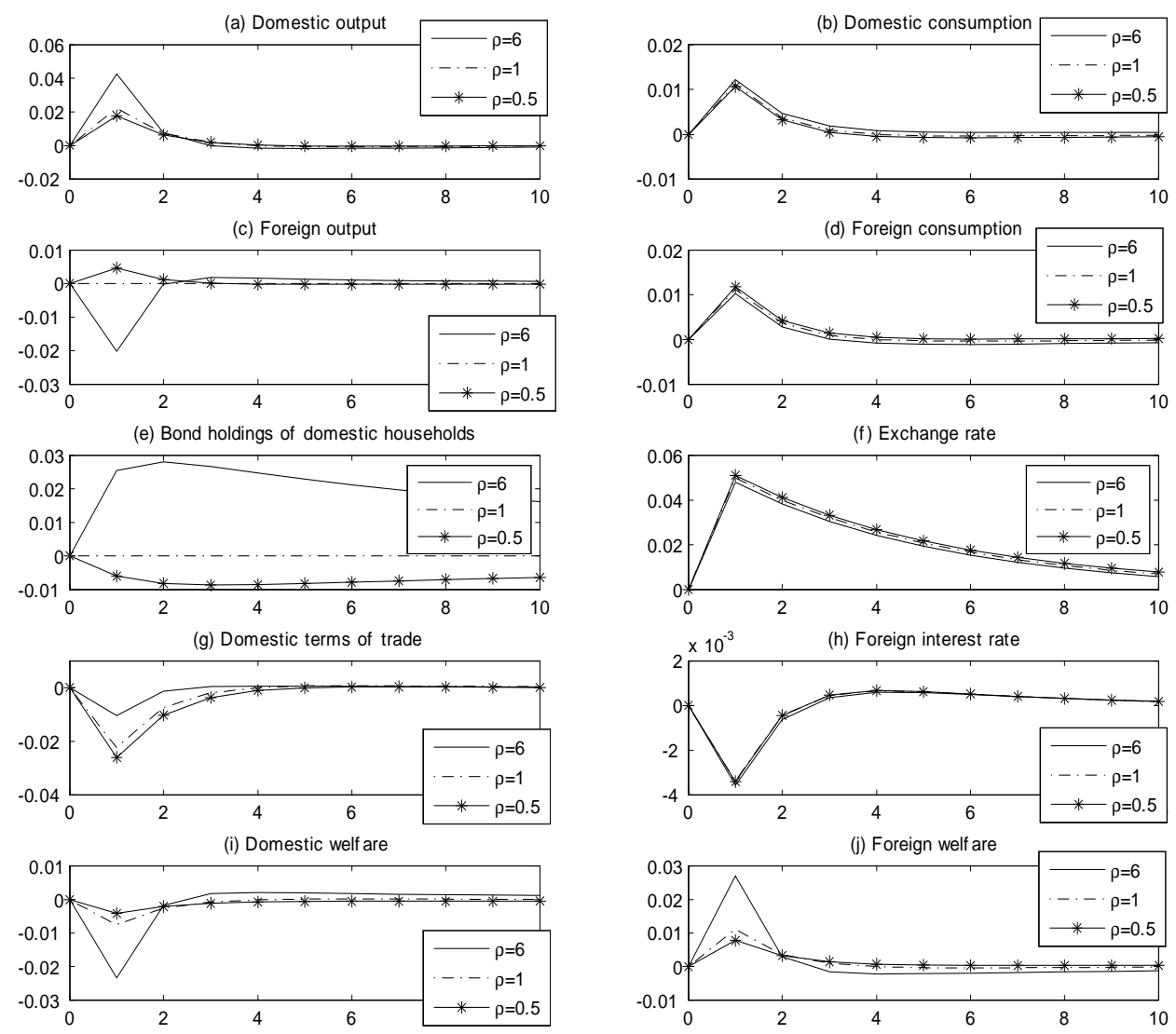
Figure 3: Dynamic Effects of a Shock to the Domestic Monetary Policy Rule under Local Currency Pricing
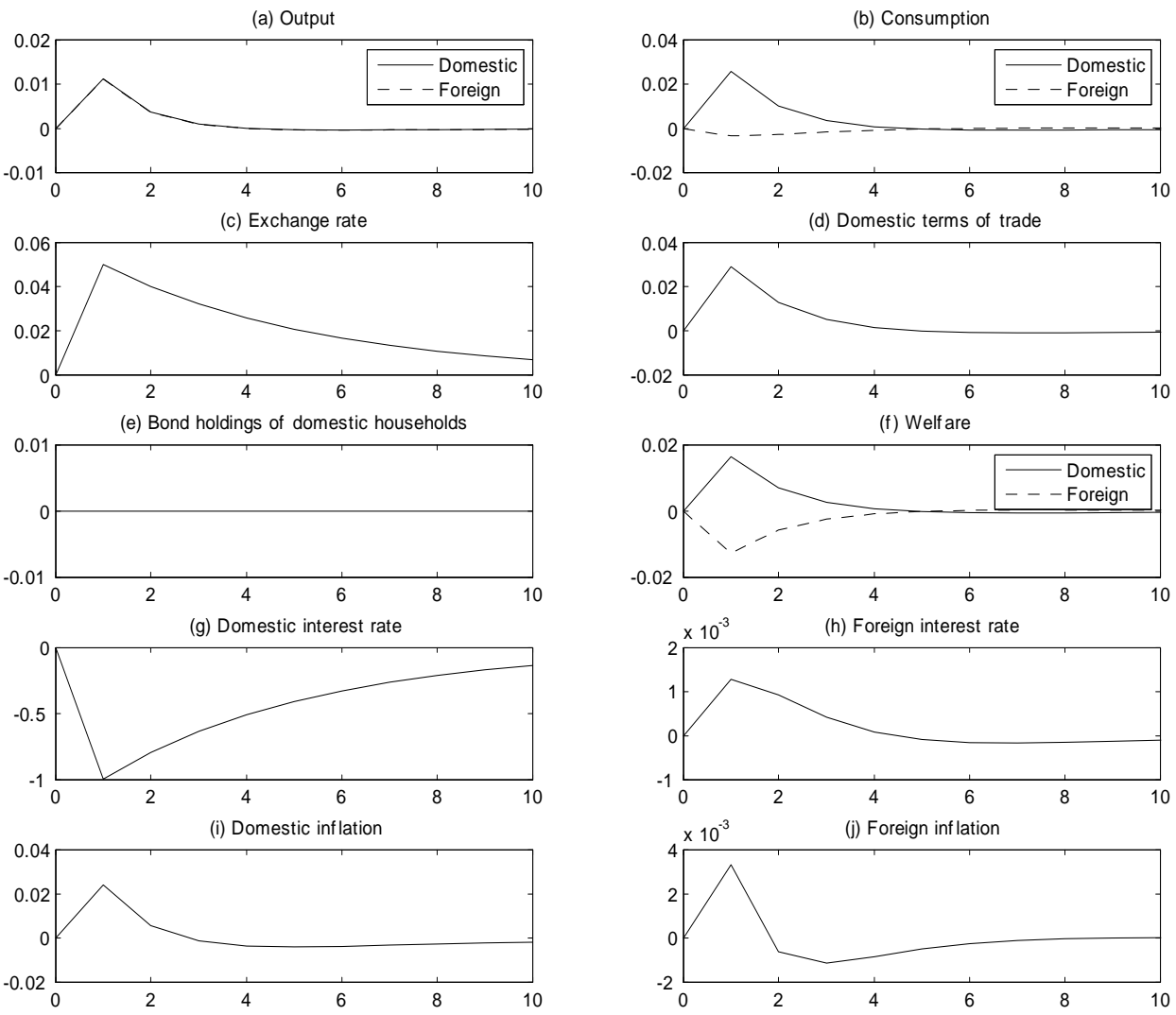
Figure 4: Dynamic Effects a Domestic Monetary Shock under Local Currency Pricing and Producer Currency Pricing $(\theta=6)$
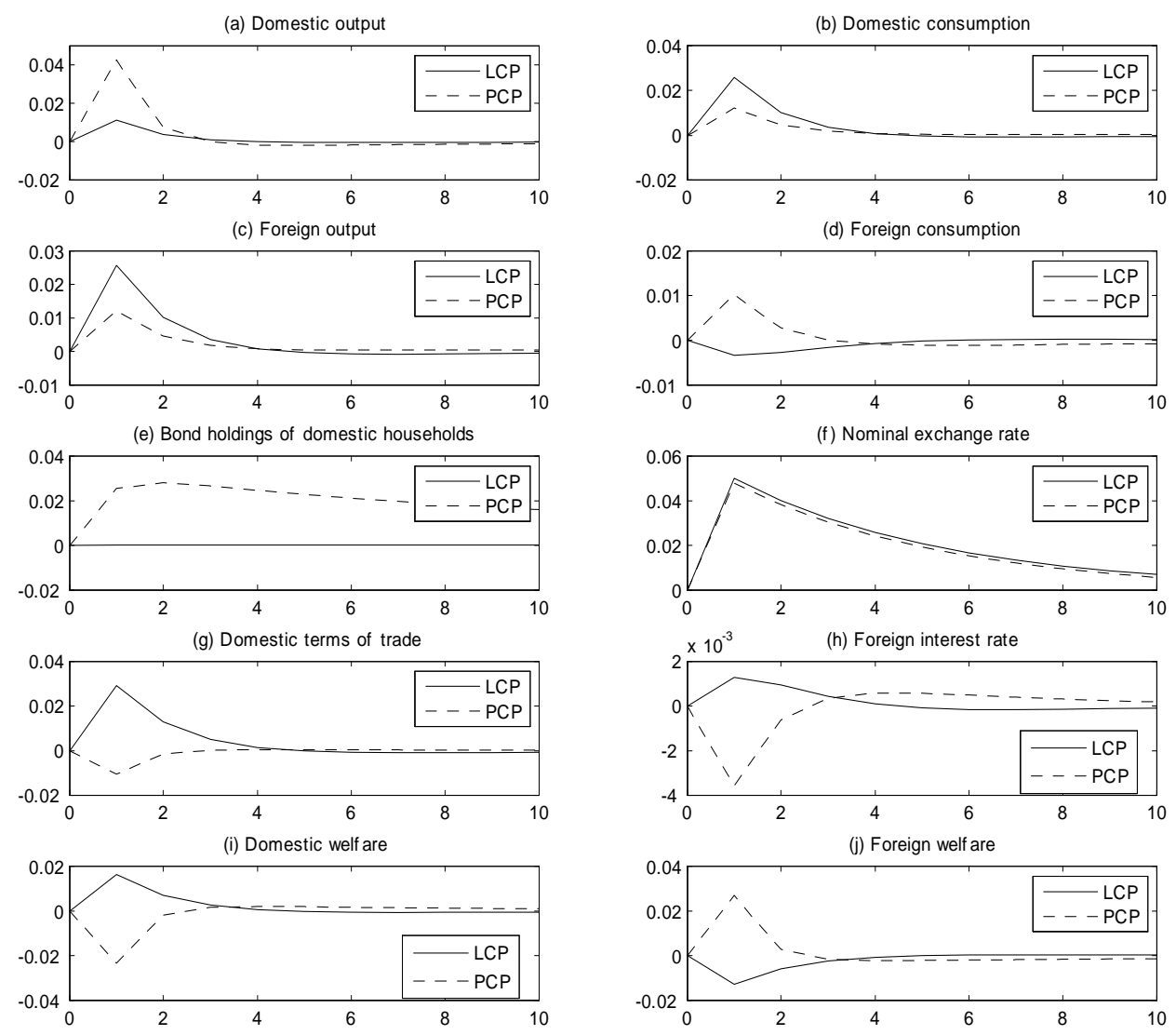
Aboa Centre for Economics (ACE) was founded in 1998 by the departments of economics at the Turku School of Economics, Ảbo Akademi University and University of Turku. The aim of the Centre is to coordinate research and education related to economics in the three universities.

Contact information: Aboa Centre for Economics, Taloustieteen laitos, Assistentinkatu 7, FI-20014 Turun yliopisto, Finland.

Aboa Centre for Economics (ACE) on Turun kolmen yliopiston vuonna 1998 perustama yhteistyöelin. Sen osapuolet ovat Turun kauppakorkeakoulun kansantaloustieteen oppiaine, Åbo Akademin nationalekonomi-oppiaine ja Turun yliopiston taloustieteen laitos. ACEn toiminta-ajatuksena on koordinoida kansantaloustieteen tutkimusta ja opetusta Turun kolmessa yliopistossa.

Yhteystiedot: Aboa Centre for Economics, Taloustieteen laitos, Assistentinkatu 7, 20014 Turun yliopisto.

www.ace-economics.fi

ISSN 1796-3133 